\title{
Soil Investigation at Wet World Hot Spring Complex for Future Development using Active Multichannel Analysis of Surface Waves
}

(Penyelidikan Tanah di Kompleks Mata Air Panas Wet World bagi Pembangunan Masa Hadapan menggunakan Analisis Pelbagai Saluran Aktif Gelombang Permukaan)

\author{
Amin E. KhaliL*, Mohd NAWAwi, M. HARIRI ARIFIn, FAthi M. AbDUllah, J.S. Kayode, \\ NURADDEEN USMAN \& ARISONA
}

\begin{abstract}
Development of hot spring touristic projects receives more interest in Malaysia in recent years since the country has a high potential of hot springs that are vital to the economy. However, such developmental activities could produce negative impacts if not accompanied with adequate knowledge of the subsurface conditions. Active multichannel analysis of surface waves (MASW) was applied to determine the subsurface shear wave velocities and Vs30. The inverted shear waves velocity models have then presented in both vertical cross-sectional plots and depth slices maps. Depth slices were chosen at about 5, $18.5 \mathrm{~m}$ and $32 \mathrm{~m}$ depths. Model obtained showed that the soil is stiffer near the highway side and turns to be softer as we go away in the scrub direction. Vs30 is also estimated and mapped to show the quality of the soil. Inverted parameters showed that the soil at the site ranges from soft soil to stiff one. Also, the result obtained proposed that the surface occurrence of the hot spring might be a result of intersection of faulted segments, where hot spring is located near the intersection points. Furthermore, the model helped in proposing a suitable for complex extension. The proposed is chosen such that it minimize any possible effects on the geothermal resources at the site.
\end{abstract}

Keywords: Hot springs; MASW; Pedas; shear wave velocity; soil properties

\section{ABSTRAK}

Pembangunan projek pelancongan mata air panas menerima minat yang lebih di Malaysia dalam beberapa tahun kebelakangan kerana negara mempunyai potensi tinggi daripada mata air panas yang penting kepada ekonomi. Walau bagaimanapun, aktiviti pembangunan ini boleh menghasilkan kesan negatif jika tidak disertakan dengan pengetahuan yang mencukupi tentang keadaan subpermukaan. Analisis pelbagai saluran aktif oleh gelombang permukaan (MASW) telah digunakan untuk menentukan kelajuan gelombang subpermukaan ricih dan Vs30. Model halaju gelombang ricih songsang ini telah dibentangkan dalam kedua-dua plot hirisan lintang menegak dan hirisan kedalaman peta. Hirisan kedalaman telah dipilih pada 5, $18.5 \mathrm{~m}$ dengan kedalaman $32 \mathrm{~m}$. Model yang diperoleh menunjukkan bahawa tanah adalah lebih keras berhampiran lebuh raya tetapi bertukar lembut ke arah belukar. Vs30 juga dianggar dan dipetakan untuk menunjukkan kualiti tanah. Parameter songsang menunjukkan tanah di tapak ini berjulat daripada tanah lembut kepada tanah keras. Selain itu, keputusan yang diperoleh mencadangkan bahawa permukaan mata air panas ini mungkin terjadi hasil daripada persilangan segmen tersesar dengan mata air panas terletak berhampiran dengan titik persimpangan. Selain itu, model ini membantu dalam mencadangkan pengembangan kompleks yang sesuai. Cadangan ini dipilih kerana ia meminimumkan sebarang kesan pada sumber geoterma di tapak ini.

Kata kunci: Halaju gelombang ricih; MASW; mata air panas; Pedas; sifat tanah

\section{INTRODUCTION}

Malaysia is characterized by the presence of numerous hot springs which are mainly of non-volcanic origin (Hassan et al. 2014; Samsudin et al. 1997; Sum et al. 2010). Most of the hot springs is used for recreation and tourism purposes. Recently, more focus on using hot springs as energy resources was observed. As more investments are being injected into the sector, new development plans were proposed to build extensions to the present complexes for more relaxation purposes. The risk that this extension may have negative impacts on the hot water flow was raised and considered seriously. Geophysical techniques, in general, are considered as reliable solution due to its non-invasive nature and efficiency.

Active MASW technique was used by numerous researchers to investigate near-surface shear waves velocity structures (Gosar et al. 2008; Long et al. 2007; Miller et al. 1999; Parker 2002; Park et al. 2001, 1999a, 1999b, 1999c; Seshunarayana \& Sundararajan 2004; Tokeshi et al. 2013). The technique was chosen due to its non-invasive nature and its simple acquisition and inversion. 


\section{GENERAL GEOLOGY AND SITE DESCRIPTION}

Ibrahim and Mustafa (2010) indicated that Pedas is considered as sub-basin of the Linggi river basin, abbreviated as LRB. According to their work, the area is composed mainly of igneous and metasedimentary rocks with the northeastern part of the basin being dominated by granitic ridges and mountains predominated in the north-western regions with plutonic and acidic rocks with patches of hypabyssal-vein quartz. The igneous rocks of the area are mainly granitic with rare occurrences of serpentinite and late phase intrusions. The granites of the area are typically medium to coarse grained rocks, often porphyritic (Alexander 1968). However, various fine-grained granites also occur and they often contain tourmaline together with muscovite and biotite. Granodiorites and adamellites are probably the most common types and biotite usually contains ferromagnesian silicate.

The research area is located in the vicinity of Seremban Fault Zone that lies within the West Belt Granite intrusion (Figure 1). The Seremban Fault zone was recently recognized by curvilinear NW-SE striking faults, south of the Kuala Lumpur Fault Zone. The NWSE faults are commonly associated with large quartz reefs, especially in the Pedas area (Hutchison \& Tan 2009). Meanwhile, Khalid and Derksen (1971) reported that the faults in Seremban are commonly associated with large quartz and pegmatitic dykes; Mylonites, sheared granites, and wide breccia zones characterizing the fault zone within the granites. The present study area is located between the boundary of the granite and metamorphosed rocks called, Pilah Schist. This formation is predominantly of grey carbonaceous shale; siltstone, phyllite and Schist with minor beds of Arenite, Slate, Limestone and volcanics (Khoo 1972).

\section{METHODS}

Surface waves constitute most of the seismic energy produced by seismic sources in any conventional seismic surveying. Rechart et al. (1970) concluded that Rayleigh waves constitute about $2 / 3$ of the seismic energy produced by the conventional seismic source (e.g. Sledgehammer). Such energy carries information about the shallow geologic media in which it travels through.

The use of surface wave dispersion characteristics has long been used in global seismology. In such a context, inversion techniques have been developed to retrieve information from measured surface wave dispersion (Nolet 1981; Takeuchi \& Saito 1972). However, the pioneer work of Gabriels et al. (1987) represent the first use of the concept of MASW to determine the shear wave velocity at shallow depths.

Dispersion is a term that describes the change of phase velocity with frequency. In the case of elastic half space (i.e. no velocity changes with depths), no surface

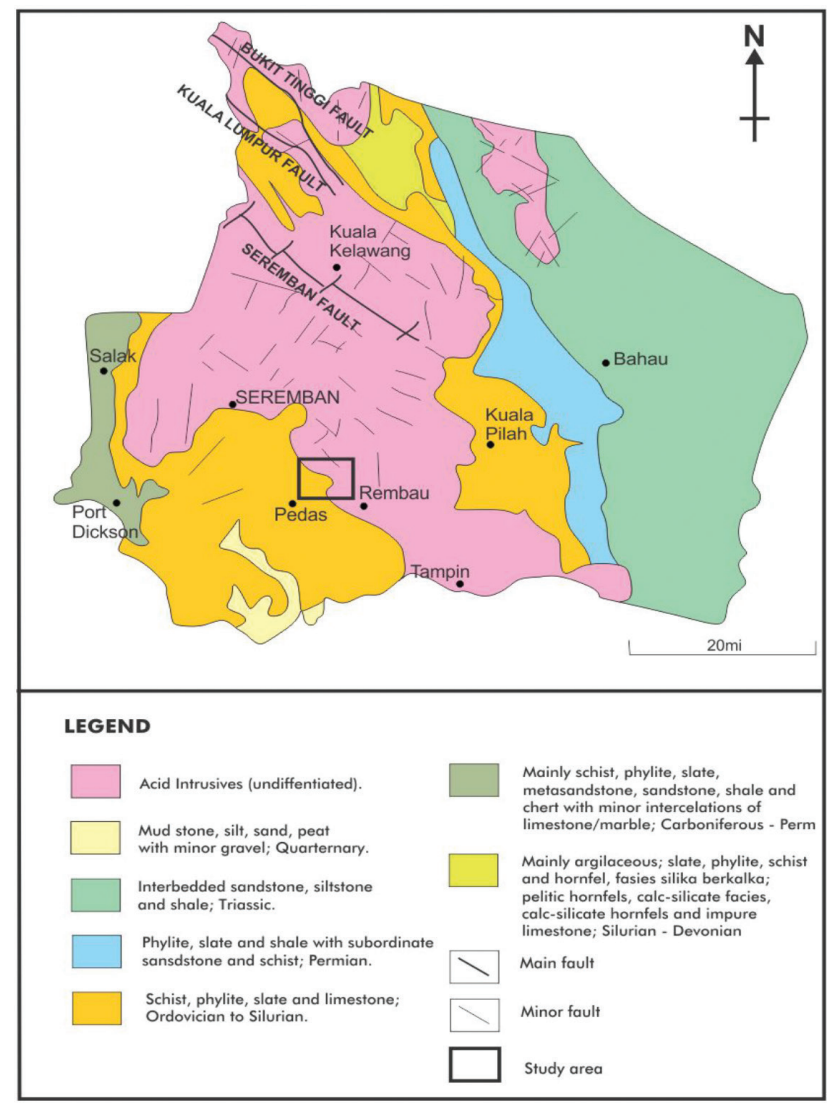

FIGURE 1. Geologic settings in the vicinity of the study area 
waves dispersion will occur. Dispersion will occur only when velocity changes vertically. At high frequencies, the wavelengths are short, and the propagation velocity is controlled by the wave-speed of the shallow soil layers (which are usually of low speed). As the frequencies decrease, the wavelengths are increasing causing the wave to penetrate to deeper layers which have higher velocities. In the present study, the area is sampled using 52 source locations at $5 \mathrm{~m}$ source intervals. The optimum source offset was chosen to be $15 \mathrm{~m}$ based on test conducted at the site. A land streamer with 24 vertical geophones at one-meter inter-distance is used for the data acquisition. Field recording was obtained with TERRALOCK MK- 8 with a sampling interval of $1 \mathrm{msec}$. The total window length was chosen to be about $1 \mathrm{sec}$.

The important piece of information here is to determine the dispersion curve. Numerous techniques are currently available. For the present work, we adopted the $\mathrm{f}-\mathrm{k}$ technique for dispersion curve determination. Foti et al. (2000) gave an elaborated discussion of the method. Sample F-K spectra are presented in Figure 2.

The target depth depends on the array parameters and local soil conditions. A depth of $30 \mathrm{~m}$ is usually targeted for the sake of soil classification according to NEHRP. Such depth cannot be achieved using 1-D analysis of the data. However, in the present work 2-D analysis is applied to reach the desired depth. At the final stage, mapping of $\mathrm{V}_{S 30}$ is presented to define the most suitable site for the future development of the site under investigation according to NEHRP classification of soils.

\section{DisCUSSION OF RESULTS}

The site under investigation was sampled using 52 MASW spreads. Geometrically, the sampling is arranged in three parallel profiles pattern. Two profiles are long with a total length of $125 \mathrm{~m}$. The third one is shorter (about $60 \mathrm{~m}$ ) because of the current land use at the site.

The inverted shear velocity model of profile 1 (Figure 3(a)), shows that down to a depth of $5 \mathrm{~m}$, the shear wave velocities are in the range of $180 \pm 20 \mathrm{~m} / \mathrm{s}$. Shear wave velocities tend to show a general increase with depth. At a depth of about $12 \mathrm{~m}$, the soil becomes stiffer reaching to shear wave velocity of about $360 \mathrm{~m} / \mathrm{s}$. As the depths are increased beyond, the soil becomes stiffer as the shear wave velocity reaches about $460 \mathrm{~m} / \mathrm{s}$. An interesting feature was encountered near the center of the profile adjacent to the surface location of the hot spring. At that place, shear wave velocities, are relatively lower than the surrounding counterparts. This could reflect the presence of deformed soil (possibly fractured zone) that enabled hot water to flow into the earth's surface.

In profile 2 (Figure $3(\mathrm{~b})$ ), by and large, the situation is the same as in profile 1 . With the exception that relatively, soft materials with shear wave velocity less than 360 $\mathrm{m} / \mathrm{s}$ are thickening and reached the depth of about $40 \mathrm{~m}$ extending from the start of the profile up to a distance of about $60 \mathrm{~m}$. Adjacent to the hot spring site, an anomaly similar to that delineated in profile 1 still present.

The third profile is shorter as previously discussed and is subtended by the area adjacent to the hot spring and the southeastern border of the site (Figure 3(c)). Adjacent to the hot spring, the low shear wave velocity anomaly continues and widening more compared to the case in profile 2 . This gives the impression that this anomaly takes the form of triangle, in aerial sense, whose head near the hot spring and base in the jungle or bush area. It may represent the intersection of two faults at the site under investigation. Maximum shear wave velocity along

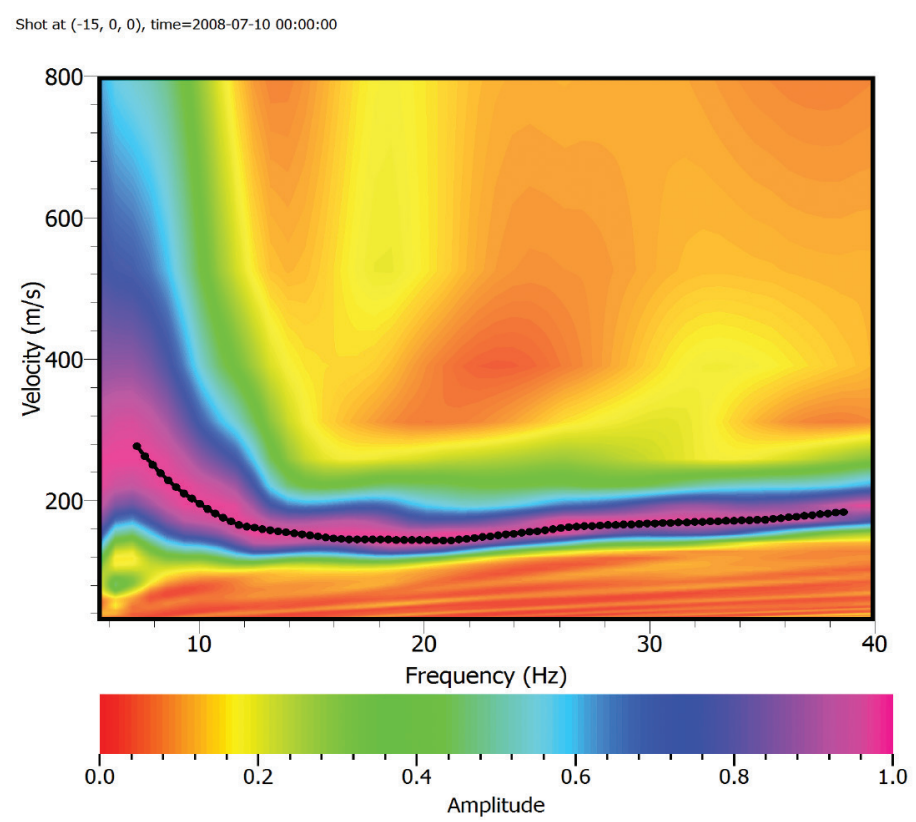

FIGURE 2. A sample of $\mathrm{f}-\mathrm{k}$ analysis and picking of dispersion curve 

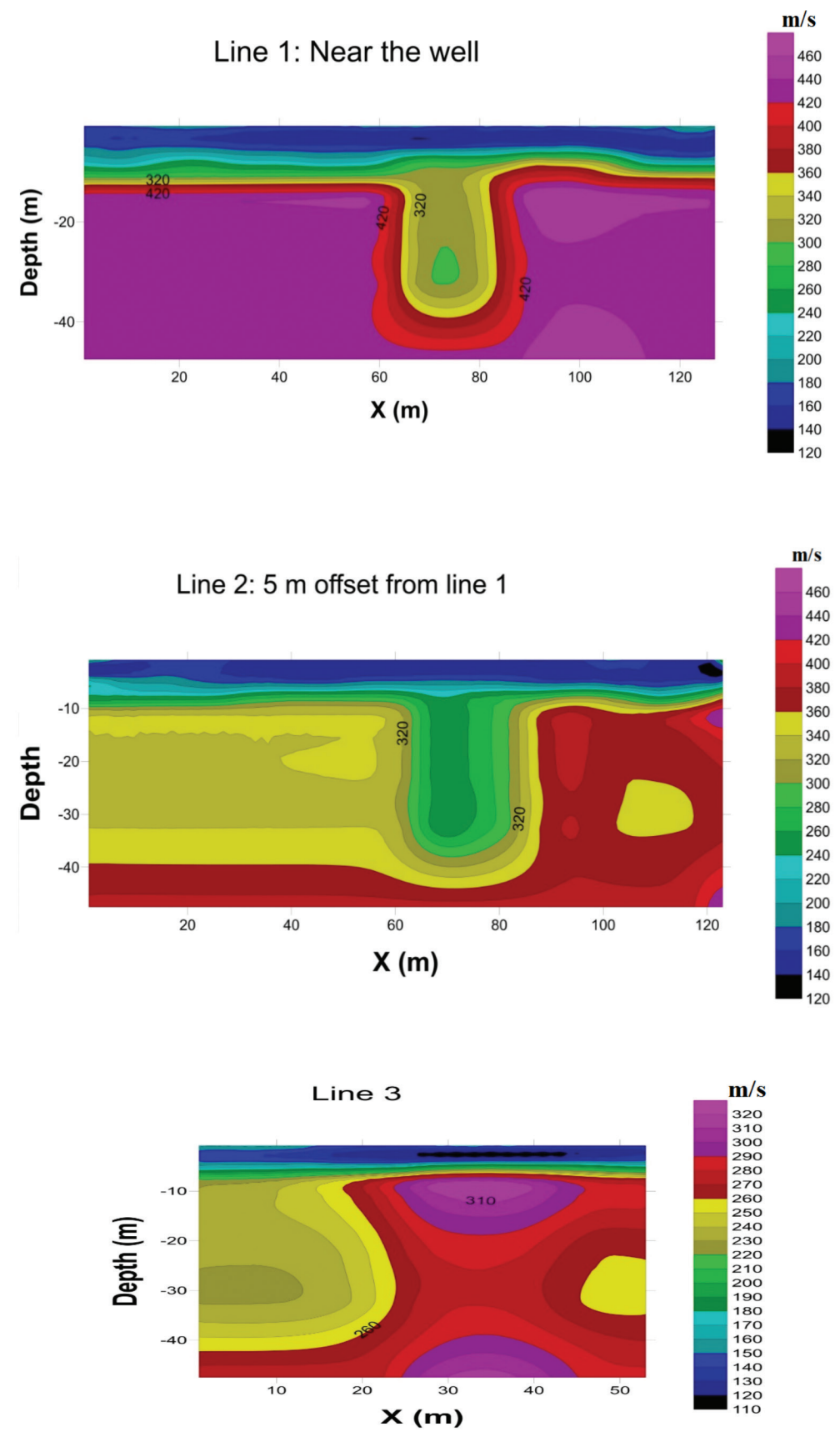

FIGURE 3. Shear-wave velocity model of profile 3 in the study area

this profile is relatively lower than the other two profiles with a maximum velocity of about $310 \mathrm{~m} / \mathrm{s}$.

In addition to the 2-D view of the inverted shear wave velocity, aerial views of the inverted model are represented by three depth slices at 5, 18, $32 \mathrm{~m}$ and Vs30 are shown in Figure 4. At $5 \mathrm{~m}$ depths, the soil is soft with shear wave velocity ranging between 140 and $220 \mathrm{~m} / \mathrm{s}$. The soil at this depth shows no special characters from the space point of view. As the depths increase, features related to possible structures of the area become visible. A triangle shape like anomaly is visible with its head near the hot spring surface location. The areas marked with symbols ' $\mathrm{A}$ ' and ' $\mathrm{B}$ ' on the site comprises the highest shear wave velocity. No big changes could be observed in both the 18 and $30 \mathrm{~m}$ depth slices. This could be interpreted as both depth slices are cutting through the same soil layer. Vs30 calculation enables classification of soil according to NEHRP (Table 1). From the map view of Vs30, at the site, three regions could be observed and classified according to their Vs30 values. Regions marked with letters ' $A$ ' and ' $B$ ' corresponding to Vs30 greater than $360 \mathrm{~m} / \mathrm{s}$ are classified as stiff soil to rock soil type. The rest of the site shows Vs30 less than $360 \mathrm{~m} / \mathrm{s}$ which is termed as soft to stiff soil classes. 

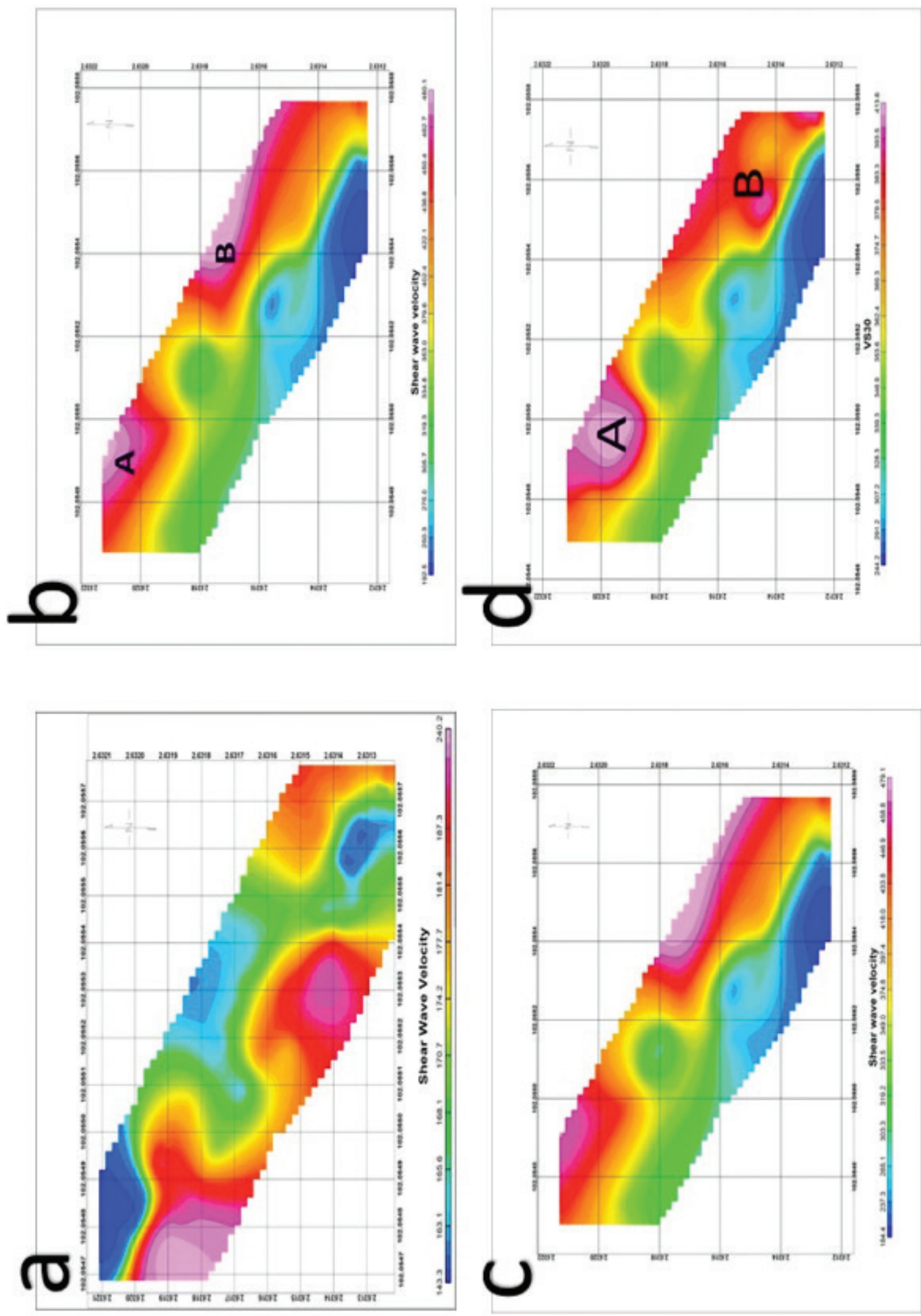

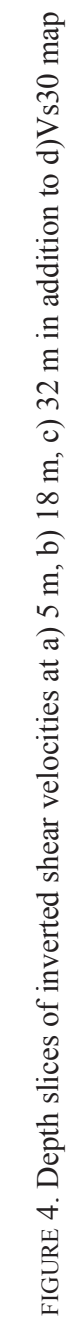


TABLE 1. Caltrans/NEHRP Soil profile types

\begin{tabular}{clccc}
\hline Site class & Soil profile name & \multicolumn{1}{c}{$\mathrm{V}_{\mathrm{s} 30}$} & \multicolumn{1}{c}{ SPT N-value } & Undrained shear strength \\
\hline A & Hard rock & $>1500 \mathrm{~m} / \mathrm{s}$ & $\ldots \ldots \ldots$ & $\ldots \ldots \ldots$ \\
B & Rock & 760 to $1500 \mathrm{~m} / \mathrm{s}$ & $\ldots \ldots \ldots .$. & $\ldots \ldots \ldots$ \\
C & Very dense soil and soft rock & $360-760 \mathrm{~m} / \mathrm{s}$ & $>50 \mathrm{bpf}$ & $>100 \mathrm{ka}$ \\
D & Stiff soil & 180 to $360 \mathrm{~m} / \mathrm{s}$ & 15 to $50 \mathrm{bpf}$ & 50 to $100 \mathrm{ka}$ \\
E & Soft soil & $<180 \mathrm{~m} / \mathrm{s}$ & $<15 \mathrm{bpf}$ & $<50 \mathrm{ka}$ \\
F & Soils requiring evaluation & $\ldots \ldots \ldots$. & $\ldots \ldots \ldots$ & $\ldots \ldots \ldots$ \\
\hline
\end{tabular}

\section{CONCLUSION}

For the current study area, extension plans are needed to increase the capacity of the site. Hence, soil investigations are required to determine the soil nature and propose the most suitable site for such extensions. Preserving the present surface occurrence of the hot spring is also a target of the assigned geophysical work. In order to achieve these objectives, MASW was chosen to model the distribution of subsurface shear wave velocity down to a depth of about $30 \mathrm{~m}$. MASW was carried out along three profiles at the site. The lengths of the profiles were controlled by the present land use of the compound. Accordingly, we have two long profiles with lengths of about $125 \mathrm{~m}$ and a shorter one with a length of about $60 \mathrm{~m}$. The array used composed of 24 geophones with an inter-geophone distances of about $1 \mathrm{~m}$. The inverted shear wave velocity model is represented both as a 2-D profiles and depth slices to characterize mutually their depths and aerial features.

Interesting features were observed from the inverted shear wave velocity. At the area adjacent to the present surface occurrence of hot spring, an anomaly of relative lower shear velocities is observed. This anomaly could be related to a deformed zone that shows low rigidity. From the aerial view at about 18 and $32 \mathrm{~m}$ depths slices, the low rigidity zone takes a triangular form with its head near the hot spring. This feature may represent an intersection of two fault segments that paved the way for the surface flow of hot water (Figure 5).

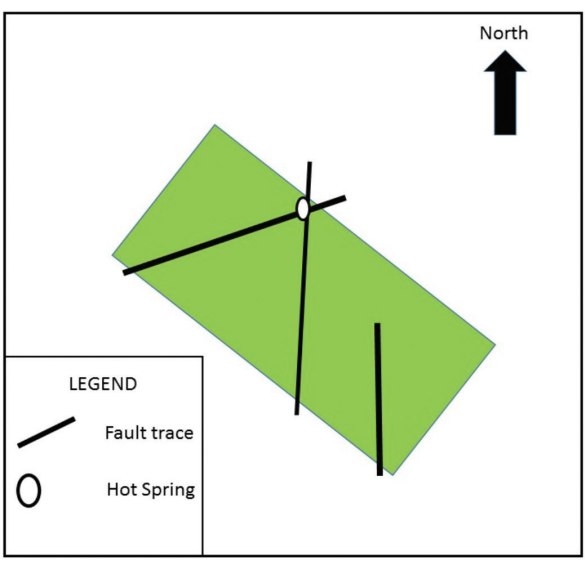

FIGURE 5. Sketch of possible geological interpretation of inverted MASW shear wave velocities
In order to classify the soil at the site, Vs30 was calculated and mapped. The classification follows NEHRP as shown in Table 1. In the Vs30 map of the site, we have two regions marked letters ' $A$ ' and ' $B$ ' with Vs30 greater than $360 \mathrm{~m} / \mathrm{s}$. The soil at these two locations is classified as stiff soil to rock. The rest areas on the site, show low Vs30 (less than $360 \mathrm{~m} / \mathrm{s}$ ) which may be classified as soft soil. From the results obtained, it is recommended that the extension plan to take place at both locations ' $\mathrm{A}$ ' and ' $\mathrm{B}$ '.

\section{REFERENCES}

Alexander, J.B. 1968. The geology and mineral resources of the neighborhood of Bentong, Pahang and adjoining portions of Selangor and Negri Sembilan. Mal. Geol. Survey Mem. (NS) 8: 1-250.

Foti, S., Lancellotta, R., Sambuelli, L. \& Socco, L. 2000. Notes on fk analysis of surface waves. Annali di Geofisica 43(6): 1199-1209. http://doi.org/10.4401/ag-3683

Gabriels, P., Snieder, R. \& Nolet, G. 1987. In situ measurements of shear-wave velocity in sediments using higher mode rayleigh waves. Geophys. Prospect. 35: 187-196.

Gosar, A., Stopar, R. \& Roser, J. 2008. Comparative test of active and passive multichannel analysis of surface waves (MASW) methods and microtremor HVSR method. RMZ - Materials and Geoenvironment 55(1): 41-66.

Hassan Baioumy, Mohd Nawawi, Karl Wagner \& Mohd Hariri Arifin. 2014. Geochemistry and geothermometry of non-volcanic hot springs in West Malaysia. Journal of Volcanology and Geothermal Research 290: 12-22. doi:10.1016/j.jvolgeores .2014.11.014.

Hutchison, C.S. \& Tan, D.N.K. 2009. Geology of Peninsular Malaysia. Kuala Lumpur: University of Malaya \& Geological Society of Malaysia. p. 480.

Khalid, B.N. \& Derksen, S.J. 1971. Geology of Eastern half of sheet 103. Ann. Report Geological Survey Malaysia. File Report. Kuching: Min. Agriculture and Land, Gov. Printing Office.

Khoo, K.K. 1972. Geology of Bahau area. Sheet 104 (Kuala Pilah) Negri Sembilan. Ann. Rep. Geol. Survey Malaysia. pp. 93-103.

Long, M. \& Donohue, S. 2007. In situ shear wave velocity from multichannel analysis of surface waves (MASW) tests at eight Norwegian research sites. Canadian Geotechnical Journal 44(5): 533-544. doi:10.1139/T07-013.

Miller, R.D., Xia, J., Park, C., Ivanov, J. \& Williams, E. 1999. Using MASW to map Bedrock in Olathe, Kansas. 69th Ann. Internat. Mtg. 99: 433-436. doi:10.1190/1.1821045. 
Nolet, G. 1981. Linearized inversion of (teleseismic) data. In The Solution of the Inverse Problem in Geophysical Interpretation, edited by Cassinis, R. New York: Plenum Press. pp. 9-37.

Parker, H.E. 2002. Multi-channel analysis of surface waves (MASW) in Karst terrain: Implications for detecting subsidence features and lineaments. University of Georgia. Thesis and Dissertations (Unpublished).

Park, C.B., Ivanov, J., Miller, R.D., Xia, J. \& Ryden, N. 1999a. Multichannel analysis of surface waves (MASW) for pavement: Feasibility test. Proceedings of the 5th SEGJ International Symposium, Tokyo, pp. 25-30.

Park, C.B., Miller, R.D. \& Xia, J. 1999b. Multi-channel analysis of surface waves (MASW). Geophysics 64(3): 800-808.

Park, C.B., Miller, R.D., Xia, J., Hunter, J.A. \& Harris, J.B. 1999c. Higher mode observation by the MASW method. SEG Technical Program Expanded Abstracts 1999. pp. 524-527. doi: 10.1190/1.1821070.

Park, C.B., Miller, R.D. \& Xia, J. 2001. Offset and resolution of dispersion curve in multichannel analysis of surface waves (MASW). Symposium on the Application of Geophysics to Engineering and Environmental Problems, October: SSM4SSM4. doi:10.4133/1.2922953.

Richart, F.E., Hall, J.R. \& Woods, R.D. 1970. Vibrations of Soils and Foundations. Englewood Cliffs: Prentice Hall.

Samsudin, A.R., Hamzah, U., Rahman, R.A., Siwar, C., Jani, M.F.M. \& Othman, R. 1997. Thermal springs of Malaysia and their potential development. Journal of Asian Earth Sciences 15(2/3): 275-284.

Seshunarayana, T. \& Sundararajan, N. 2004. Multichannel analysis of surface waves (MASW) for mapping shallow subsurface layers - A case study, Jabalpur, India. 5th Conference \& Exposition on Petroleum Geophysics, Hyderabad, India. pp. 642-646.

Sum, C.W., Irawan, S. \& Fathaddin, M.T. 2010. Hot springs in the Malay Peninsula. Proceedings World Geothermal Congress. Bali, Indonesia.

Takeuchi, H. \& Saito, M. 1972. Seismic surface waves. In Methods in Computational Physics, edited by B.A. Bolt, New York: Academic Press. 11: 217-295.
Tokeshi, K., Harutoonian, P., Leo, C.J. \& Liyanapathirana, S. 2013. Use of surface waves for geotechnical engineering applications in Western Sydney. Advances in Geosciences 35(1): 37-44. doi:10.5194/adgeo-35-37-2013.

Amin E. Khali1*

Geology Department, Faculty of Science

Helwan University

Egypt

Amin E. Khali1*, Mohd Nawawi, M. Hariri Arifin,

Fathi M. Abdullah, J.S. Kayode, Nuraddeen Usman \& Arisona School of Physics, Universiti Sains Malaysia

11800 USM, Penang, Pulau Pinang

Malaysia

M. Hariri Arifin

Geology Programme

Faculty of Science and Technology

Universiti Kebangsaan Malaysia

43600 UKM, Bangi, Selangor Darul Ehsan

Malaysia

\section{Fathi M. Abdullah}

Geology Department, Faculty of Applied Science

Taiz University, Taiz 6803

Yemen

*Corresponding author; email: aminwej@gmail.com

Received: 8 May 2016

Accepted: 9 September 2016 